\title{
Plumbemia em população urbana
}

\author{
Lead reference values in the blood of the urban population
}

\section{Senhor Editor}

Como membro do Grupo de Assessores (199698) da Revista de Saúde Pública, gostaria de registrar a discordância com a forma como foi justificado o trabalho publicado por Monica M. B. Paolielo e colaboradores, no número 31(2):144-8, 1997, sobre "Valores de referência para plumbemia em população urbana".

Refiro-me à não-citação dos diversos trabalhos brasileiros sobre plumbemia de populações não ocupacionalmente expostas - adultos e crianças -, e à imediata comparação dos achados de Londrina-PR com os achados da Itália, da Holanda e mesmo Cingapura, sem qualquer alusão aos valores de referência estabelecidos por autores brasileiros.

Entendemos que tanto os estudos pioneiros de Durval João Canella, divulgados em 1964 - sempre citados em literatura especializada sobre toxicologia ocupacional e ambiental brasileira - como os estudos mais recentes, quer os desenvolvidos por Nilda Fernícola e Fausto Azevedo, publicados em 1981, quer os de Eládio Santos Filho e colaboradores, publicados em 1993 - entre vários outros - constituem referências mínimas obrigatórias, sempre que se pretende estudar e publicar sobre o tema, no Brasil.

Por isto, foi ligeira demais a expressão dos autores de que "praticamente não existe uma base de da-

\section{BIBLIOGRAFIA}

FERNÍCOLA, N.A. \& AZEVEDO, F.A. Níveis de chumbo e atividade de desidratase do ácido delta-aminolevulínico (deltaALAD) no sangue da população da Grande São Paulo, Brasil. Rev. Saúde Pública, 15(3):272-82, 1981.

SANTOS FILHO, E. et al. Concentrações sangüíneas de metais pesados e praguicidas organoclorados em crianças de 1 a 10 anos. Rev. Saúde Pública, 27(1):59-67, 1993. dos para obtenção de tais valores. Por esse motivo, os valores de referência utilizados advêm de estudos realizados em outros países, onde as condições socioeconômicas, clínicas, nutricionais e ocupacionais diferem bastante das brasileiras".

Nossas observações não pretendem diminuir o mérito dos colegas da Universidade Estadual de Londrina. Ao contrário, apenas reforçam nosso cuidado em valorizar a produção científica brasileira escassa, é verdade, mas preciosa - bem como se alinham à admirável preocupação do ilustre editor da Revista de Saúde Pública, quando busca valorizar o idioma de nosso país, bem como sua rica produção científica, como, aliás, tão bem o fez no mesmo número da Revista, no Artigo Especial sobre O Brasil e a Medicina Tropical.

Belo Horizonte, 22 de julho de 1997. René Mendes Departamento de Medicina Preventiva e Social Faculdade de Medicina da UFMG

SPÍNOLA, A.G.; FERNÍCOLA, N.A.; MENDES, R. Intoxicação profissional por chumbo. In: MENDES, R. (Ed.) Medicina do Trabalho - Doenças Profissionais. São Paulo, Sarvier, 1980. p. 437-60. 
Senhor Editor,

Em referência à carta do Prof. René Mendes, a qual se refere à ausência de citação de bibliografia nacional no trabalho intitulado "Valores de Referência para Plumbemia em população urbana", agradecemos ao professor pela lembrança dos três artigos mencionados.

Temos a considerar que tais artigos e textos eram de nosso conhecimento, e que, em momento algum, a não-citação dos mesmos teve qualquer conotação de desmerecimento dos trabalhos. Pelo contrário, são de autores pioneiros e que muito têm contribuído para o desenvolvimento da Toxicologia no Brasil.

Concordamos que as publicações são preciosas, mas segundo as suas próprias palavras, são escassas, e por isso o uso da expressão de "praticamente" não existirem dados. Ademais, o trabalho publicado por Santos Filho se refere apenas a crianças de 1 a 10 anos, o qual não foi objeto de nosso estudo. Em relação ao trabalho de Fernícola e Azevedo, o obje- tivo dos autores não foi estabelecer valores de referência e sim comparar níveis de plumbemia em populações com diferentes graus de exposição. $\mathrm{O}$ nosso objetivo não era realizar um estudo epidemiológico, mas estabelecer valores de plumbemia em populações ditas de referência, por se tratar de metodologia específica. Apesar disso, concordamos com o Prof. René Mendes que a citação seria pertinente no conjunto dos resultados obtidos.

Londrina, 20 de agosto de 1997 Monica Maria Bastos Paolielo Departamento de Patologia Aplicada, Legislação e Deontologia Centro de Ciências da Saúde Universidade Estadual de Londrina 